\title{
IPTEKS BANTUAN SOSIAL BERDASARKAN STANDAR AKUNTANSI PEMERINTAHAN DI KANTOR WILAYAH KEMENTERIAN AGAMA PROVINSI SULAWESI UTARA
}

\author{
Yustanti A. Radjak ${ }^{1}$, Oliviana Kojo ${ }^{2}$, Dian Ardhina Lacoro ${ }^{3}$, Jenny Morasa ${ }^{4}$ \\ 1,2,3,4 Jurusan Akuntansi, Fakultas Ekonomi dan Bisnis Universitas Sam Ratulangi, Jl. Kampus Unsrat, Manado, \\ 95115, Indonesia \\ E-mail : yustantiaradjak@gmail.com
}

\begin{abstract}
Social assistance is the provision of assistance in the form of money or goods provided from the Central Government to the Regional Government or central institutions in the region. The expenditure / burden of social assistance in the Regional Office of the Ministry of Religion of North Sulawesi Province is in accordance with Government Accounting Standards (GAS). for procedures for social assistance that have been going well, can be seen from the procedures stipulated in the proposal until the disbursement of funds or goods. Presentation of financial statements using accrual methods makes it easier for the government to produce accurate government financial reports.
\end{abstract}

Keywords: Government Accounting Standards, Social Assistance

\section{PENDAHULUAN}

Pemerintah Indonesia harus berkerjasama dengan pemerintah luar negeri maupun dengan perusahaan atau masyarakat dalam hal ini kerjasama dalam bentuk bantuan. Bantuan yang dimaksud yaitu bantuan sosial. Secara umum, bantuan sosial merupakan bentuk penyerahan dana ataupun barang yang diberikan Pemerintah Pusat kepada pemerintah atau lembaga-lembaga pusat yang ada di daerah. Untuk pemberian bantuan sosial harus dilakukan dengan cara melihat aspek kebutuhan dan keadilan serta bermanfaat untuk masyarakat sehingga jauh dari kepentingan pribadi maupun kepentingan politik. Pemerintah harus lebih teliti lagi dalam hal memberikan bantuan, agar pemberian bantuan bisa tepat sasaran. Karena pada kenyataannya banyak sekali orang-orang yang menyalahgunakan dana bantuan sosial tersebut. Sehingga kelompok masyarakat atau masyarakat itu sendiri yang benar-benar membutuhkan bantuan tidak mendapatkan bantuan seperti yang diharapkan. Seperti yang kita ketahui bahwa bantuan sosial digunakan untuk meringankan beban dan memulihkan kondisi masyarakat seperti kondisi ekonomi.

KanWil Kementerian Agama Prov. Sulawesi Utara adalah salah satu instansi pemerintah yang melakukan pemberian bantuan sosial berdasarkan PMA Republik Indonesia Nomor 67 Tahun 2015 yang didalamnya berisi pemberian bantuan seperti bantuan operasional, bantuan sarana dan prasarana, dan bantuan-bantuan lainnya. Bantuan sosial termasuk dalam APBN dan APBD (Buletin Teknis SAP No. 04). Penyajian laporan keuangan untuk bantuan sosial dilakukan berdasarkan SAP berbasis akrual yang sudah diterapkan di Indonesia sejak 3 tahun lalu. Dalam belanja bantuan sosial harus memenuhi prinsip-prinsip anggaran publik yaitu efektif, efisien, ekonomis, dan akuntabel. Yang menerima bantuan sosial biasanya organisasi masyarakat ataupun masyarakat pada umumnya.

\section{TINJAUAN PUSTAKA}

Standar Akuntansi Pemerintahan Berbasis Akrual. Berdasarkan SAP Berbasis Akrual (PP Nomor 71 Tahun 2010) yaitu standar dimana penerimaan, beban, asset, hutang maupun modal diakui dalam laporan keuangan berbasis acrual, juga menyetujui penerimaan, 
pengeluaran dan pembiayaan dalam pengimplementasian anggaran berdasarkan acuan basic yang sudah disahkan di dalam APBN/APBD. KSAP (Komite Standar Akuntansi Pemerintahan) telah menerbitkan beberapa Buletin Teknis yang berisi penjelasan teknis akuntansi dan penjelasan penerapan PSAP (Pernyataan Standar Akuntansi Pemerintahan). Buletin Teknis No. 10 tentang Akuntansi Belanja Bantuan Sosial dan No. 19 tentang Akuntansi Bantuan Sosial Berbasis Akrual. Buletin Teknis ini terdiri dari: pengakuan, pengukuran, pencatatan, penyajian, dan pengungkapan.

Pengertian Bantuan Sosial. Bantuan sosial adalah semua bentuk pengeluaran dari negara baik dalam bentuk transfer uang maupun barang yang nantinya akan diberikan kepada masyarakat atau kelompok organisasi yang disalurkan melalui Kementerian/Lembaga dan/atau Pemerintah Daerah yang bertujuan untuk melindungi masyarakat atau kelompok organisasi tertentu dari kemungkinan terjadinya risiko sosial (Permenkeu No. 81/PMK.05/2012). Menurut Arifuddin, Andi Kusumawati, dan Kartini Hanafi Idris (2015) di dalam bukunya yang berjudul "Kebijakan Akuntansi Pemerintah Daerah II" menyatakan bantuan sosial merupakan bentuk pemberian barang ataupun jasa yang disalurkan ke masyarakat dengan tujuan untuk menaikkan taraf kesejahteraan masyarakat yang sifatnya tidak berkelanjutan serta di seleksi.

Prosedur Bantuan Sosial. Berdasarkan Keputusan Dirjen Bimas Islam No. DJ.II/622 Tahun 2015 yang berisi tentang prosedur administrasi yang harus disiapkan untuk menerima bantuan sosial adalah sebagai berikut :

1. Melampirkan Surat Permohonan ke kepala kantor masing-masing Kabupaten/Kota.

2. Memasukkan proposal.

3. Melampirkan Rencana Anggaran biaya (RAB) kegiatan.

4. Melampirkan Surat Rekomendasi dari Kepala Kantor Kementerian Agama di masingmasing Kabupaten/Kota.

5. Melampirkan keterangan domisili (bantuan yang bersifat perorangan).

6. Melampirkan surat keterangan kebenaran dokumen bermeterai 6000 .

7. Fotokopi rekening aktif/ legalisir pihak bank.

8. Menandatangani Surat Perjanjian Kerjasama.

\section{METODE DAN TEKNIK PENERAPAN IPTEKS}

\subsection{Metode Penerapan Ipteks}

Metode ipteks yang diterapkan yaitu berdasarkan Buletin Teknis SAP (PP Nomor 71

Tahun 2010) tentang Bantuan Sosial yang berbasis acrual yang terdiri dari pengakuan, pengukuran, pencatatan, penyajian, dan pengungkapan.

\subsection{Teknik Penerapan Ipteks}

Teknik ipteks yang digunakan yaitu dengan berdasarkan Buletin Teknis Standar Akuntansi Pemerintahan yang terdiri dari: pengakuan atas belanja/beban bantuan sosial, diukur dan dicatat di dalam Laporan Keuangan Pemerintah Pusat/Daerah, disajikan dalam Laporan Realisasi Anggaran (LRA) dan Laporan Operasional (LO), dan diungkap dalam Catatan Atas Laporan Keuangan (CALK).

\section{PEMBAHASAN}

\subsection{Gambaran Objek Penerapan Ipteks}

KanWil Kementerian Agama Prov. Sulut bertempat di Jalan 17 Agustus, Manado, Sulawesi Utara. Kepala Kantor Wilayah Kementerian Agama yang pertama yaitu A.R.M Agus Ahmad Dhalan (1951-1956) dan sekarang Kepala Kantor Wilayah Kementerian Agama Prov. Sulawesi Utara yaitu Dr. H. Abdul Rasyid M.Ag yang menjabat dari tahun 2017. Visi dari KanWil Kementerian Agama Prov. Sulut yaitu, "Terwujudnya Masyarakat Indonesia yang Taat Beragama, Rukun, Cerdas, dan Sejahtera Lahir Batin dalam Rangka Mewujudkan 
Indonesia yang Berdaulat, Mandiri, dan Berkepribadian Berlandaskan Gotong Royong" (Keputusan Menteri Agama Nomor 39 Tahun 2015). Sedangkan misi dari Kantor Wilayah Kementerian Agama Prov. Sulawesi Utara adalah, meningkatkan pengetahuan dan profesionalisme ajaran agama, menstabilkan ketentraman intra dan antar umat beragama, mengadakan bantuan untuk kehidupan umat beragama yang meluas dan bermutu, menaikan pendayagunaan dan kualitas manajemen potensi ekonomi keagamaan.

\subsection{Pembahasan}

Perlakuan akuntansi dalam Bantuan Sosial di Kantor Wilayah Kementerian Agama berdasarkan Buletin Teknis Standar Akuntansi Pemerintahan, sebagai berikut:

1. Pengakuan. Belanja Bantuan Sosial diakui saat terjadinya pengeluaran dalam bentuk uang maupun barang/jasa dari rekening kas umum negara/daerah. Sedangkan Beban Bantuan Sosial diakui ketika adanya hutang di laporan keuangan.

2. Pengukuran dan Pencatatan. Belanja Bantuan Sosial diukur dan dicatat sesuai dengan nilai nominal yang dikeluarkan untuk pembayaran Belanja Bantuan Sosial. Untuk Beban Bantuan Sosial diukur sesuai dengan jumlah uang, barang/jasa yang diserahkan kepada penerima bantuan sosial yaitu kelompok/organisasi masyarakat atau masyarakat itu sendiri. Belanja/Beban bantuan sosial dicatat dalam Laporan Keuangan Pemerintahan Pusat.

3. Penyajian. Belanja Bantuan Sosial disajikan di dalam Laporan Realisasi Anggaran (LRA), dan untuk Beban Bantuan Sosial disajikan di dalam Laporan Operasional Kantor Wilayah Kementerian Agama. Apabila bantuan sosial tersebut belum diberikan kepada penerima bantuan sosial, maka bantuan sosial dimasukkan ke dalam Neraca dan disebut sebagai persediaan pada laporan keuangan.

4. Pengungkapan. Belanja/Beban Bantuan Sosial di Kantor Wilayah Kementerian Agama diungkap di dalam Catatan Atas Laporan Keuangan (CALK). CALK berguna untuk mengungkap jenis pengeluaran Bansos menurut akseptor Bansos serta mengungkap persediaan bantuan sosial.

Prosedur Bantuan Sosial Pada KanWil Kementerian Agama Prov. Sulawesi

Utara. Tahap pertama yaitu memasukkan proposal, kemudian penerima bantuan sosial akan diseleksi proposalnya oleh instansi tempat pemberi bantuan sosial. Apakah pemohon benarbenar membutuhkan bantuan tersebut dan telah memenuhi kriteria penerima bantuan atau tidak. Selanjutnya jika proposal tersebut lolos seleksi maka pemohon harus melengkapi beberapa berkas, yaitu yang pertama memasukan surat permohonan. Setelah permohonan usulan diterima pihak pemohon selanjutnya diminta untuk memasukan proposal kegiatan yang sudah diseleksi dalam hal ini proposal bantuan sosial dengan menyertakan surat rekomendasi dari Kepala Kantor Kementerian agama yang berada di Kabupaten/Kota, beserta berkas-berkas pendukung lainya seperti fotokopi wajib pajak organisasi (Nomor pokok wajib pajak), melampirkan Anggaran Dasar/Anggaran Rumah Tangga organisasi, fotokopi rekening aktif atau legalisir dari pihak bank, menyertakan nomor kontak yang dapat dihubungi, melampirkan surat keterangan kebenaran dokumen, serta menandatangani surat perjanjian kerjasama antar pihak.

\section{KESIMPULAN DAN SARAN}

\subsection{Kesimpulan}

Perlakuan akuntansi terhadap Belanja/Beban Bantuan Sosial pada KanWil Kementerian Agama Prov. Sulut sudah mengacu pada Buletin Teknis SAP No. 10 dan No. 19. Untuk prosedur bantuan sosial pada KanWil Kementerian Agama Prov. Sulut telah dilakukan berdasarkan tahapan yang telah disahkan. Dilihat dari prosedur-prosedur yang ditetapkan dalam pengusulan proposal sampai dengan pencairan dana atau barang bantuan sosial. Diharapkan penyajian laporan keuangan menggunakan metode akrual lebih mudah 
dalam membantu pemerintah dalam menyajikan laporan keuangan pemerintah agar lebih akurat, transparan dan akuntabilitas.

\subsection{Saran}

1. KanWil Kementerian Agama Prov. Sulut wajib mengarah pada Buletin Teknis SAP Nomor 10 dan Nomor 19 agar perlakuan akuntansi atas bantuan sosial tetap berjalan dengan baik sesuai dengan Standar Akuntansi Pemerintahan yang berlaku.

2. Proses tindak lanjut dari proposal harus lebih ditingkatkan, agar pencairan dana untuk bantuan sosial lebih cepat terealisasikan. Dan sebaiknya petugas front office Pelayanan Terpadu Satu Pintu harus mewakili setiap Bidang Bimbingan Masyarakat agar penerimaan proposal dalam bentuk apapun langsung diterima sesuai dengan bidangnya.

\section{DAFTAR PUSTAKA}

Peraturan Pemerintah No. 71 Tahun 2010 tentang Standar Akuntansi Pemerintahan Berbasis Akrual. Jakarta

Peraturan Menteri Keuangan No. 81/PMK.05/2012 tentang Bantuan Sosial pada Kementerian/Lembaga. Jakarta

Buletin Teknis Standar Akuntansi Pemerintahan No. 19 tentang Akuntansi Bantuan Sosial Berbasis Akrual. Jakarta

Buletin Teknis Standar Akuntansi Pemerintahan No. 10 tentang Akuntansi Belanja Bantuan Sosial. Jakarta

Buletin Teknis Standar Akuntansi Pemerintahan No. 04 tentang Penyajian dan Pengungkapan Belanja Pemerintah. Jakarta

Keputusan Direktur Jenderal Bimbingan Masyarakat Islam Nomor DJ.II/622 Tahun 2015 tentang Petunjuk Teknis Pemberian Bantuan Pemerintah di Lingkungan Direktorat Jenderal Bimbingan Masyarakat Islam. Jakarta

Arifuddin., Andi Kusumawati dan Kartini Hanafi Idris. 2015. Kebijakan Akuntansi Pemerintah Daerah II. Yogyakarta. LeutikaPrio

Sianturi, Holmes. 2017. Kedudukan Keuangan Daerah Dalam Pengelolaan Dana Hibah dan Bantuan Sosial Berdasarkan Perspektif Keuangan Negara. Bandung. Jurnal Wawasan Yuridika. Vol. 1, No. 1: 86-106

Muaja, L. R. 2014. Perlakuan Akuntansi Bantuan Sosial Terhadap Laporan Keuangan Pada Pemerintah Daerah Kota Manado. Manado. Jurnal EMBA. Vol. 2, No. 1: 510-520

Titisari, Friska Dyah. 2014. Analisis Kegiatan Pengendalian Pengelolaan Belanja Hibah dan Belanja Bantuan Sosial (Studi Kasus: Pemerintah Kota Magelang). Skripsi. Tidak Diterbitkan. Universitas Kristen Satya Wacana. Salatiga

Rahmawati, Novi. 2016. Studi Penetapan dan Pengelolaan Dana Hibah dan Dana Bantuan Sosial di Surakarta. Tugas Akhir. Tidak Diterbitkan. Universitas Muhammadiyah Surakarta. Surakarta

Peraturan Menteri Agama Republik Indonesia Nomor 67 Tahun 2015 tentang Bantuan Pemerintah Pada Kementerian Agama. Jakarta 